University of Nebraska - Lincoln

DigitalCommons@University of Nebraska - Lincoln

U.S. National Park Service Publications and

Papers

National Park Service

1997

\title{
Constraints On Frugivory By Bears
}

Christy A. Welch

Washington State University

Jeffrey Keay

National Biological Service, jeff_keay@usgs.gov

Katherine C. Kendall

USGS-NRMSC Science Center, kkendall@usgs.gov

Charles T. Robbins

Washington State University, ctrobbins@wsu.edu

Follow this and additional works at: https://digitalcommons.unl.edu/natlpark

Welch, Christy A.; Keay, Jeffrey; Kendall, Katherine C.; and Robbins, Charles T., "Constraints On Frugivory By Bears" (1997). U.S. National Park Service Publications and Papers. 56.

https://digitalcommons.unl.edu/natlpark/56

This Article is brought to you for free and open access by the National Park Service at DigitalCommons@University of Nebraska - Lincoln. It has been accepted for inclusion in U.S. National Park Service Publications and Papers by an authorized administrator of DigitalCommons@University of Nebraska - Lincoln. 


\title{
CONSTRAINTS ON FRUGIVORY BY BEARS
}

\author{
Christy A. Welch, ${ }^{1}$ Jeffrey Keay, ${ }^{2}$ Katherine C. Kendall, ${ }^{3}$ And Charles T. Robbins ${ }^{4}$ \\ 'Department of Natural Resource Sciences, Washington State University, Pullman, Washington 99164-6410 USA \\ ${ }^{2}$ National Biological Service, Alaska Science Center, Denali Field Station, Denali National Park and Preserve, \\ P.O. Box 9, Denali Park, Alaska 99755 USA \\ ${ }^{3}$ National Biological Service, Science Center, Glacier National Park, West Glacier, Montana 59936 USA \\ ${ }^{4}$ Departments of Natural Resource Sciences and Zoology, Washington State University, \\ Pullman, Washington 99164-6410 USA
}

\begin{abstract}
Bears consuming wild fruits for fall energy accumulation are constrained by several factors, including intake rate, the physiological capacity of the gastrointestinal tract, and the metabolic efficiency of gain in body mass. We measured these relationships through foraging and feeding trials using captive and wild black bears (Ursus americanus) and grizzly bears (Ursus arctos). Four fruit types covering a range of sizes and clustering were offered to captive bears to determine the effect of density, size, and presentation on intake rate. Intake rate (in grams per minute) and bite rates (in bites per minute) increased curvilinearly with increasing fruit density in singly spaced fruits. Maximum intakes ranged from $30 \mathrm{~g} / \mathrm{min}$ for $0.5-\mathrm{g}$ berries to $>200 \mathrm{~g} / \mathrm{min}$ for $4.2-\mathrm{g}$ fruits. The highest bite rates were obtained during the initial encounter with each patch as bears consumed all visually apparent fruits on the surface. Bite rates quickly dropped by $15-20 \%$ as foraging continued within the patch. Maximum bite rates were not depressed until initial fruit density fell to $<50$ berries $/ \mathrm{m}^{3}$. Maximum daily fresh fruit intake for the captive bears averaged $34 \pm 6 \%$ (mean $\pm 1 \mathrm{SD}$ ) of body mass. The dry-matter digestibility of wild fruits, particularly preferred species, was as high as $72 \%$. While large captive bears could gain body mass very rapidly when given fruit ad libitum, foraging efficiencies increasingly constrained growth rates of wild bears $>100 \mathrm{~kg}$. We concluded that large bears, such as grizzlies, must depend on plants that permit large bite sizes or high bite rates through fruit clustering and bush configuration that reduce leaf-to-fruit ratios.
\end{abstract}

Key words: bears; berries; body mass; digestibility; foraging efficiency; fruits; gastrointestinal capacity; intake rate; metabolic efficiency; reproductive success; Ursus americanus; Ursus arctos.

\section{INTRODUCTION}

Wild fruit is an important summer and fall food for black bears and grizzly bears throughout eastern and northwestern North America (Hatler 1972, Pearson 1975, Mace and Jonkel 1986, Rogers 1987, Schwartz and Franzmann 1991). Bears rely heavily on small, wild fruits such as berries to provide energy reserves necessary for reproduction and winter hibernation, especially in areas where energy-dense foods (e.g., salmon) are scarce or unavailable. Even bears consuming fall mast (e.g., acorns) may depend on small fleshy fruits for survival in years of mast crop failure (Eiler et al. 1989). Because bears are non-cecal monogastrics that cannot digest fiber efficiently, they cannot significantly increase their fat stores on foliage alone (Poelker and Hartwell 1973, Bunnell and Hamilton 1983, Eagle and Pelton 1983). Thus, small wild fruits play an important role in sustaining many bear populations.

Studies of bear food habits are numerous and exist for nearly every region of North America. However, because bears are omnivores, these studies are often merely natural history descriptions of the vast array of

Manuscript received 3 August 1995; revised 4 August 1996; accepted 3 September 1996. food items found in a particular area. Such studies rarely link the nutritional value of the food items with the nutritional requirements of the bear, or identify the mechanical and physiological factors that limit the bear's food intake. Several studies have found general relationships between berry abundance and bear reproductive success, but these also have been specific to particular areas (Jonkel and Cowan 1971, Rogers 1976, Young and Ruff 1982, Schwartz and Franzmann 1991). Because most field studies focus on bear natural history at a scale that does not permit detailed foraging measurements, little attention has been given to quantifying foraging constraints that would apply broadly to bears foraging in any ecosystem. These constraints include: (1) the interaction between berry size, density, and presentation that determines the bear's bite size, bite rate, and intake rate, (2) the physical and physiological capacity of the bear's gastrointestinal tract to process fruits that determines the maximum theoretical daily dry-matter intake, and (3) the interaction between energy intake, digestibility, and gain in body mass that determines the efficiency of bears in converting fruit to new tissue.

We hypothesize that one of the primary foraging constraints on berry-eating bears is harvesting or intake 
rate (i.e., amount of food consumed per unit time). Intake rate is the product of two variables: bite rate and bite size. We hypothesize that both of these variables will be influenced by berry density, size, and presentation (e.g., single or clustered and distribution within the patch). Bite rate for bears foraging on berries is determined by two competing processes: (1) the search time required to locate berries that are dispersed among leaves and (2) the time required to mechanically crop a bite. As berry density increases or the presentation changes from single berries randomly distributed throughout the bush to being concentrated in the bush's canopy or in clusters from a single inflorescence, berries become more apparent, and search time is reduced. As search time approaches zero, bite rate approaches its maximum and produces a concurrent increase in intake rate. If the bear moves directly from berry to berry at a constant rate, then the bear's bite rate and, therefore, intake rate should be related to the square root of berry density (nearest neighbor distance: Pielou 1977, Spalinger et al. 1988, Spalinger and Hobbs 1992). We also hypothesize that berry size affects intake rate by constraining bite size, especially at low densities where berry and bite size may be equal. At high berry densities or when berries are clustered, bears should be able to procure more than one berry per bite. Thus, berry density and presentation will influence intake rate not only by influencing bite rate but also by affecting bite size. The current study focuses at the scale of the individual patch.

By quantifying the constraint variables, we can test several ecologically relevant hypotheses. For example, we hypothesize that the smaller black bear will have a competitive advantage over the larger grizzly when feeding on small, singly spaced berries in areas of relatively low berry productivity, but that grizzlies are more competitive when berry abundance or presentation allows for the higher intake rate necessary to sustain their larger body size. Similarly, we hypothesize that berry crop persistence may be as important as crop size, the more frequently measured parameter. Thus, a general model of the constraints on bear foraging may provide insight necessary to understand the ecology and management of black bears and the threatened grizzly bear and provide direction for future research.

\section{Methods}

\section{Foraging trials}

Two captive grizzly bears and two captive black bears, an adult female and a yearling male of each species, were used for the foraging trials. The captive bears were housed at the Washington State University Bear Research Facility in Pullman, Washington. They were normally fed a variety of foods, including dry pelleted rations, deer (Odocoileus virginianus), apples (Malus spp.), fresh grass, and salmon (Oncorhynchus tshawytsha). Bears were habituated to the protocol at the beginning of the berry season through numerous "practice" trials. All bears were initially fasted for $\geq 12 \mathrm{~h}$ preceding a set of trials in order to achieve maximum intake rates. However, due to substantial plasticity in individual bear behavior, pre-trial fasting was tailored to achieve maximum performance for each bear. Once consistent behavior and a high level of interest were achieved, experimental trials were initiated.

To determine the effect of fruit size and density on bite rate, bite size, and intake rate, we selected four types of "berries" and two types of presentation that encompassed much of the range of fruit sizes and densities found in natural habitats $(0.05$ to $8.37 \mathrm{~g}$ fresh mass/berry and 35 to 1700 berries/m² (Hatler 1967, Noyce and Coy 1990, Powell and Seaman 1990)). We chose huckleberry (Vaccinium membranaceum and $V$. globulare) as the smallest berry size (mean $=0.40$ $\mathrm{g} /$ berry, fresh mass) because it is highly preferred by bears (Martinka 1976, Bacon and Burghardt 1983, Mace and Jonkel 1986), locally abundant, and singly spaced. Serviceberry (Amelanchier alnifolia) was used as a second berry type because the berries are larger (0.6 g/berry, fresh mass), preferred by bears (Martinka 1976, Eagle and Pelton 1983, Mace and Jonkel 1986), and often occur in clusters of 3-5 berries. Because larger, highly preferred, singly spaced berries were unavailable locally, we created artificial berry bushes by hot-gluing small (mean fresh mass $=1.8 \mathrm{~g}$ ) and large (mean $=4.2 \mathrm{~g}$ ) seedless red grapes to Vaccinium shrubs. Grapes were used because they are similar to huckleberries in being highly preferred by bears and low in fiber (Spiller 1993).

Huckleberry and serviceberry bushes were collected from the nearby national forests in northern Idaho and northeastern Washington. Shrubs were clipped at the base, the stems were placed in water, and they were then transported to the Bear Research Facility. By using Vaccinium shrubs to create the artificial bushes in which the huckleberries were replaced by grapes, we were able to vary berry size by ten-fold while holding shrub size and configuration constant.

Berry "patches" for the trial were constructed by inserting the bushes into holes drilled in a plywood base. Nine holes were uniformly placed $15 \mathrm{~cm}$ apart in a $1.9 \mathrm{~cm}$ thick $(3 / 4-i n c h)$ plywood base that measured $0.5 \times 0.5 \mathrm{~m}$. Bushes were arranged in these holes to create a uniform patch $\approx 0.5 \mathrm{~m}$ high. Patches were used for only one trial because of damage as the bear foraged and due to possible complications that may have occurred if one bear detected another bear's odor or saliva on the bushes.

The number of berries in the patch was determined by counting each berry individually prior to a trial. Dried or unripe berries were removed to simplify analysis. Subsamples of fresh berries were removed periodically from the bushes to obtain mean berry fresh masses. Patch area was determined by photographing each patch from a standard height directly above its 


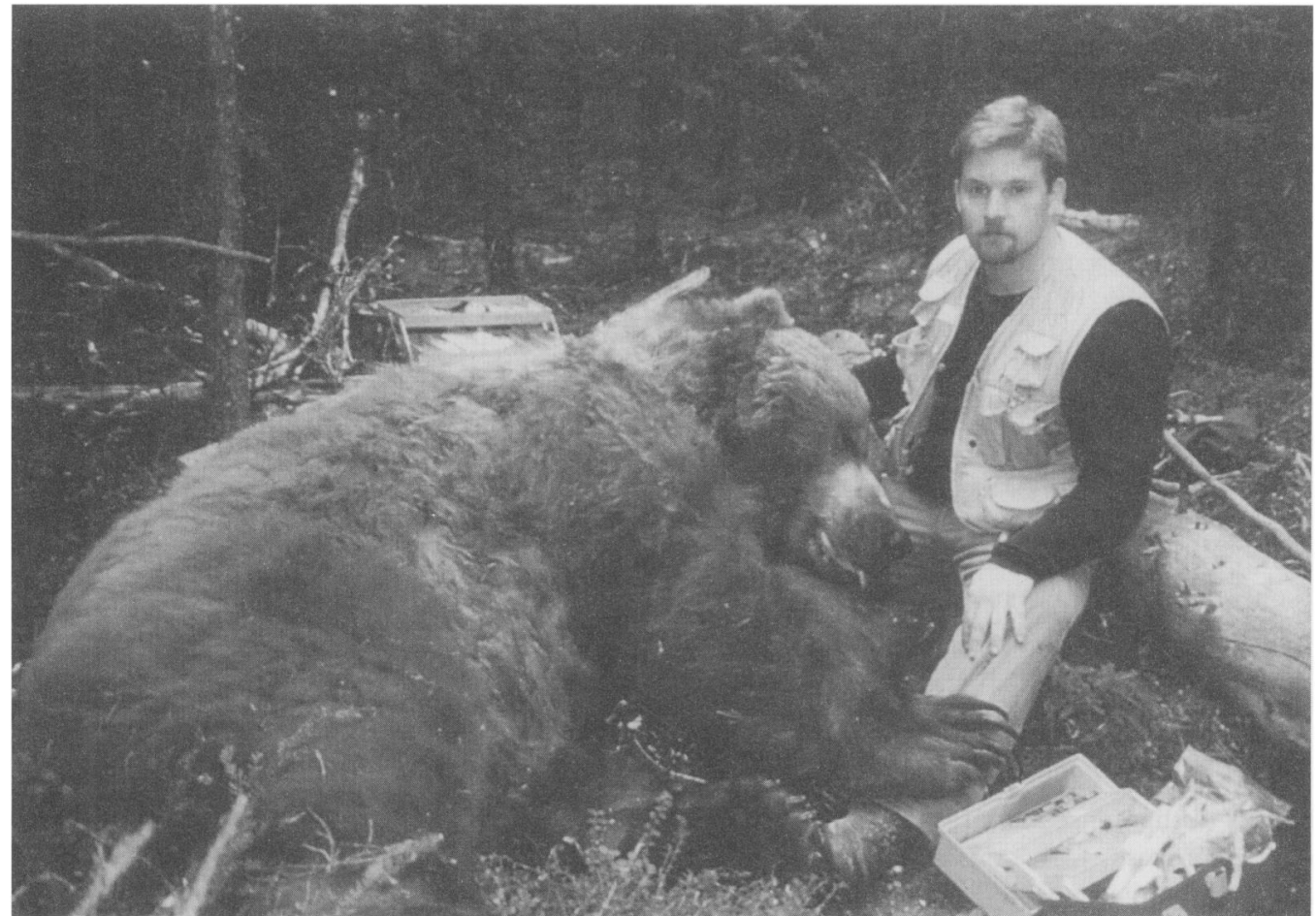

Plate 1. Illustration of the relative size of a well-nourished, wild, anesthetized grizzly bear. Although a bear of this size $(360 \mathrm{~kg}$ ) would strive to eat over 260000 huckleberries $(V$. membranaceum)/d, foraging efficiency would constrain intake to as little as 70000 berries/d and the bear would lose $1.9 \mathrm{~kg} / \mathrm{d}$. Thus, a bear of this size can only exist when salmon or other high-energy, abundant food resources are available.

center and using a Monochrome Ag Vision System (Decagon Devices, Pullman, Washington) to integrate the outside, irregular area of each patch. Mean height of the berry producing part of the patch was determined from eight measurements throughout the patch. Berry density then was expressed as berries per unit volume rather than the more common berries per unit area, because foraging occurred in a three-dimensional space.

For each trial, the plywood base supporting the berry patch was secured in a larger floor-mounted frame in the inner room of the bear's pen. The bear was then allowed access to the patch. Total trial time was measured as the time that the bear was actively foraging. Trials typically lasted 1-5 min, depending upon the number of berries available. The number of berries consumed during the trial was determined by counting the berries before and after each trial. The number of bites taken during the trial were independently counted by two observers. Because berry density decreased as the bear foraged, the number of bites taken was recorded for the first two 15- and then subsequent 30-s intervals until the trial was complete. A bite was defined as a single cropping motion of the jaws (Shipley and Spalinger 1992) that severed a berry (or berries) from the shrub.

Foraging characteristics were modeled using a nonlinear least-squares regression (Gauss-Newton algo- rithm, SAS 1985), similar to that used in other foraging studies (Wickstrom et. al 1984, Spalinger et. al 1988, Spalinger and Hobbs 1992, Shipley and Spalinger 1992, Gross et. al 1993):

$$
B=\Theta_{1} \sqrt{D} /\left(\Theta_{2}+\sqrt{D}\right)
$$

where $B$ is the average bite rate in bites per minute, $D$ is berry density in berries per cubic meter, $\Theta_{1}$ is the asymptotic, theoretical maximum bite rate, and $\Theta_{2}$ is the square root of the berry density at which bite rate is half-maximal (Real 1977). Because bite rate should correspond directly to intake rate if bite size remains constant, we applied the same model to a nonlinear regression of intake rate on berry density. To determine goodness of fit, we examined a plot of the residuals from each regression for normality and uniform scatter. The coefficient of correlation is reported using the corrected sums of squares (Motulsky and Ransnas 1987). Linear regression was used to examine the effect of increasing berry density on bite size (berries per bite). The effect of bear species was tested for significance by using a simple $F$-test (Motulsky and Ransnas 1987) for the nonlinear regressions, and ANCOVA (SAS 1985 ) for the linear regressions. We caution that all of our analyses have the limitations of relatively few bears and nonindependence of data caused by using each bear in multiple trials. While these problems are virtually unavoidable when working with captive bears, partic- 
ularly grizzly bears, the statistical analyses may underestimate the probability of a Type I error.

Because bears in captivity do not experience many of the constraints imposed on those living in natural conditions, we were concerned that the short-term foraging rates of the captive bears would not accurately reflect the sustained foraging rates of wild bears. To address this concern, wild grizzlies were observed in August and September, 1994, foraging on berries in both Glacier (northwest Montana) and Denali (interior Alaska) National Parks. Bite counts were made by the senior author in all three locations (natural and captive) in order to avoid observer bias. Observations included bite rates (bites/min), berry species consumed, and a general description of the bear's foraging behavior. Bite rates were recorded only for brief continuous time segments when the bear's snout was clearly visible and the bear was intently foraging. Time spent walking and not biting was not included in the determination of bite rates.

\section{Digestive capacity and efficiency}

In addition to the constraints imposed by the proximal foraging process, fruit consumption by bears is further limited by the capacity and efficiency of the digestive system. The maximum digestive capacity for bears consuming fruit was measured by giving them ad libitum access to domestic apples or blueberries (Vaccinium corymbosum) during the fall hyperphagia period. Blueberries and apples were used because they are highly preferred (Bacon and Burghardt 1983, Servheen 1983) but have a low energy density that forces larger intakes in order to fulfill energy requirements. Apples have an average dry matter content of $16.9 \%$ and are $72.7 \%$ digestible, whereas commercial blueberries ( $V$. corymbosum) are $17.9 \%$ dry matter and 64.2\% digestible (Pritchard and Robbins 1990; S. D. Farley and C. T. Robbins, unpublished data).

Captive grizzlies used for these trials included one adult male and two yearlings (male and female); black bears used included one male yearling and two adults (male and female). The bears were fed fruit ad libitum several days prior to and throughout a 10-d trial in order to ensure the gut was expanded to its maximum capacity. The mass of the fresh fruit offered was recorded and all orts were collected and weighed at the end of each 24-h period. Maximum daily fruit intake was calculated as the highest, consecutive 3 -d average and was plotted against the average body mass of that bear during the 10-d trial.

The digestibility of foods consumed by bears varies in relation to their fiber content (Pritchard and Robbins 1990). In order to model the effect of gastrointestinal capacity and berry digestibility on fruit consumption by wild bears, berries were collected from forests in northern Idaho, northeast Washington, northwest Montana, and coastal Alaska for nutritional analyses. The average berry mass for each species was determined by weighing 30 individual berries. Berries with micro- scopic seeds (e.g., huckleberry) were ground in a Wiley mill prior to analysis. For berries with larger seeds that are normally passed intact when consumed by bears (e.g., highbush cranberry, Viburnum edule), the berries were gently but thoroughly macerated with a pestle so the seed was left intact but the pulp was exposed. For these fruits, seeds and pulp also were physically separated and analyzed when possible to determine the relative contribution from each component. All analyses were on undried, fresh-frozen berries. Total dietary fiber and dry matter digestibility were determined as in Pritchard and Robbins (1990). Crude protein was determined by macro-Kjehldahl procedure and dry matter by drying at $100^{\circ} \mathrm{C}$ for $24 \mathrm{~h}$.

\section{Nutrient intake and rate of gain}

Thirteen 10-d trials were conducted using two captive grizzly bears (an adult female and a subadult male) and three captive black bears (two adult females and a yearling male) to determine the relationship between fruit consumption and gain in body mass. Body masses were recorded for each bear at the beginning and end of each trial, and the bears were fed diets consisting solely of apples or blueberries. The amount of fruit consumed was determined daily by calculating the difference between the fresh mass of the fruit offered and the orts collected. Linear least-squares regression was performed to determine the relationship between mass change and digestible dry matter intake.

\section{RESULTS}

\section{Foraging trials}

There were no significant differences between black and grizzly bears in intake rates or bite rates (Figs. 1 and $2, F$ value ranging from $F_{1,88}=0.103$ to $F_{1,87}=$ 1.59 , all $P$ s $>0.10$ ). Therefore, all captive bears were combined for analyses. The residuals of all regressions were normally distributed and uniformly scattered around the regression lines. For all berry sizes and presentations, intake rate during an entire foraging bout increased curvilinearly with increasing initial berry density (Fig. 1). Maximum intakes ranged from 30 $\mathrm{g} / \mathrm{min}$ for huckleberries to $>200 \mathrm{~g} / \mathrm{min}$ for large grapes. Average bite rates (bites per minute) throughout a foraging bout increased curvilinearly as initial berry density increased in three of the four sets of trials (Fig. 2 ). Average bite rates for serviceberry remained constant over a range of berry densities from 58 to 1280 berries $/ \mathrm{m}^{3}$.

However, within all trials bite rate and intake rate were highest in the early portion of the trial (Figs. 3, $4,5,6$ ). At initial fruit densities of $\approx 190$ berries $/ \mathrm{m}^{3}$ and higher, this initial decrease generally progressed into a plateau that would eventually decline shortly before the bear ceased foraging. At densities $<190$ berries $/ \mathrm{m}^{3}$, bite rate and intake rate steadily decreased, changes resulting from the different modes of foraging 


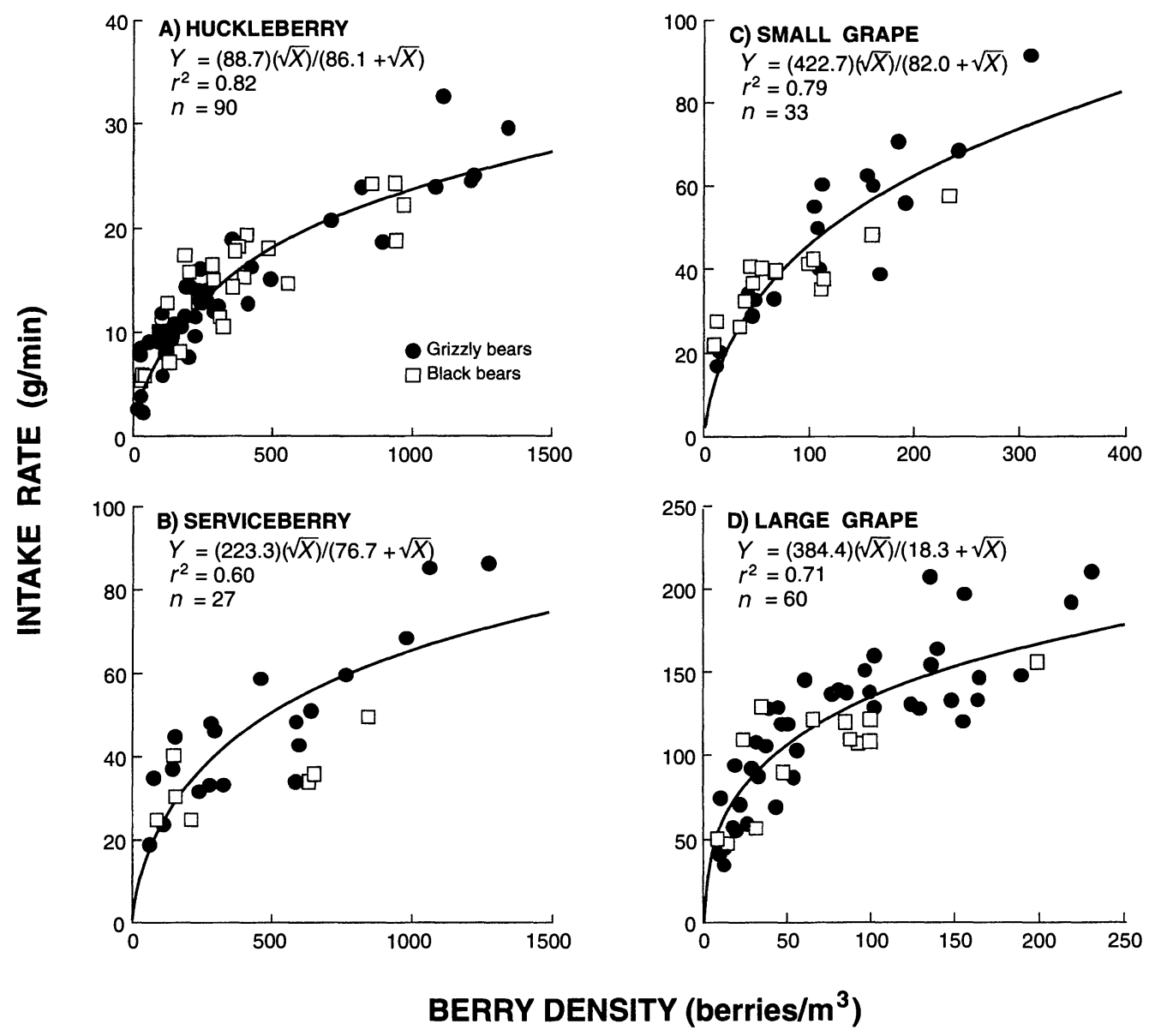

FIG. 1. Average food intake rate over an entire trial in relation to berry density for captive black and grizzly bears foraging on four different berry types. Huckleberry (Vaccinium membranaceum) and serviceberry (Amelanchier alnifolia) were natural, wild-collected bushes, while the grapes were glued individually to fruitless huckleberry bushes; $n=$ number of individual observations (one bear doing one thing).

as the trial progressed. Initially, each bear "high-graded" the patch, taking all the visually apparent berries. Bite rate dropped as the bear began to search for less visible berries within the core of the patch, often with the aid of a paw. Bite rate during the first $15 \mathrm{~s}$ showed the same trends with berry density as did average bite rate (Fig. 7). However, only at the very lowest berry densities (i.e., $<50$ berries $/ \mathrm{m}^{3}$ ) was maximum bite rate depressed. Asymptotic bite rates ranged from 36 to 57 bites/min.

The effect of bear species on the regressions between bite size and berry density was not significant (Fig. 8, all $P \mathrm{~s}>0.15$ ), so all bears were combined for analyses. Average bite sizes for the singly spaced berries ranged from 1.0 to 1.7 berries/bite with increasing berry density; all regressions were significant (Fig. 8, all $P$ s $<0.005$ ). Average bite sizes for serviceberry increased more dramatically, ranging from 1.0 to 4.6 berries/bite at densities similar to those for huckleberry $(P=$ 0.0001 ). For the majority of trials, bears moved from berry to berry or from cluster to cluster and avoided ingesting leaves, stems, or twigs. When bears took indiscriminate mouthfuls of leaves and berries, the average number of berries per bite was often lower than when the bear selected berries alone. At the very highest densities of huckleberry, one grizzly began "stripping" the branches, which were heavily laden with berries. The bear would take the branch into its mouth and rake it with teeth and lips, but averaged only 1.3 berries per bite in the process. Thus, taking less selective bites did not always result in greater intake efficiency.

\section{Comparing captive and wild bear foraging rates}

Two adult wild grizzlies were observed on separate occasions in Glacier National Park, northwest Montana, foraging on huckleberries and serviceberries on a subalpine slope. One bear was observed foraging for a period lasting $26 \mathrm{~min}$, the other for $28 \mathrm{~min}$. Bite rates averaged $53 \pm 19$ and $34 \pm 7 \mathrm{bites} / \mathrm{min}$ (mean \pm 1 SD), respectively, for the two bears. It was not possible to determine separate bite rates for huckleberry and 

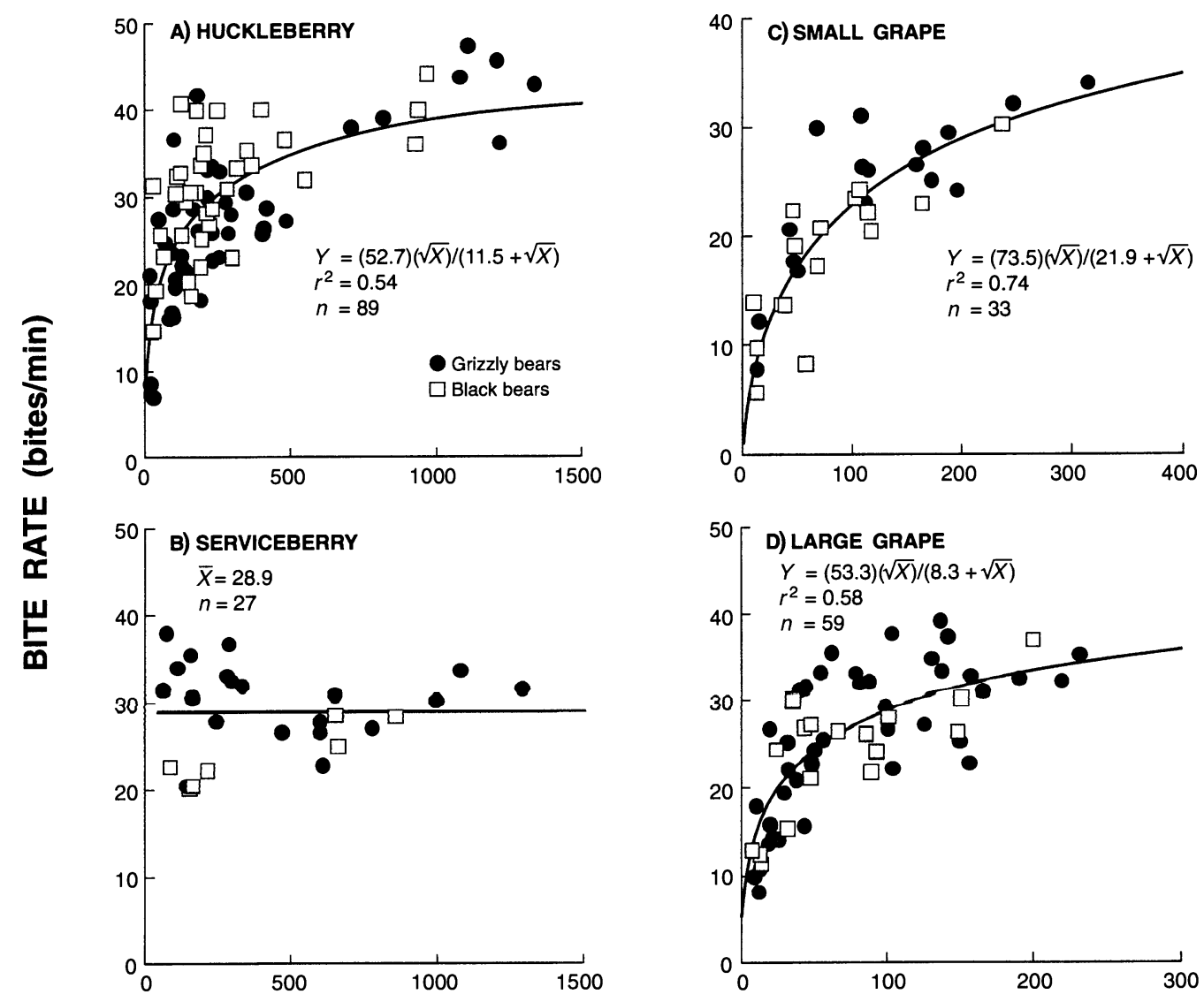

\section{BERRY DENSITY (berries $/ \mathrm{m}^{3}$ )}

FIG. 2. Average bite rate over an entire laboratory trial in relation to berry density for both black and grizzly bears foraging on four different berry types; $n$ as in Fig. 1 .

serviceberry, but these observed rates are comparable to those observed for the captive bear trials. Both bears moved constantly while foraging, stopping briefly (8204 s) to take several bites before moving on. Thus, both captive and wild bears consumed the most visually apparent berries, or high-graded.

For two grizzlies feeding in Denali National Park on soapberry (Shepherdia canadensis) for a combined total of 18 foraging minutes (biting only, no walking), bite rates ranged from 32 to 81 bites/min, with an average of $63 \pm 11 \mathrm{bites} / \mathrm{min}$ [mean $\pm 1 \mathrm{sD}$ ]. For another adult feeding on bog blueberry (Vaccinium uliginosum) for 7.2 foraging minutes, the range of bite rates was 82 to $108 \mathrm{bites} / \mathrm{min}$, with an average of $95 \pm 9$ bites/ $\mathrm{min}$. For a fourth grizzly feeding on both berry species alternately for 15 foraging minutes, bite rates averaged $90 \pm 21 \mathrm{bites} / \mathrm{min}$, ranging from 62 to $123 \mathrm{bites} / \mathrm{min}$. Bears feeding on soapberry were often observed using a paw to manipulate a branch. The soapberry berries were heavily clustered near the underside of the main stems of the shrub, and were readily apparent. Bears feeding on bog blueberry bobbed their heads up and down rapidly, vigorously stripping the bushes with apparently little or no time spent searching or identifying individual berries. The observed bite rates of the subarctic bears feeding on soapberry and bog blueberry were approximately twice as high as the bite rates observed for wild bears in Montana and the captive bears in Pullman.

\section{Digestive capacity and efficiency}

Maximum daily fresh fruit intake of the captive bears fed ad libitum averaged $34 \pm 6 \%$ (mean $\pm 1 \mathrm{sD}$, range $30-55 \%$ ) of body mass (Fig. 9). A $302-\mathrm{kg}$ grizzly consumed daily the equivalent of $>184000$ berries weighing $0.5 \mathrm{~g}$ each. Maximum intake rates for apples and blueberries were quite similar. As illustrated by Fig. 9, there were no apparent differences in maximum intake between black bears and grizzlies other than that created by the larger size of the grizzlies.

The estimated dry matter digestibility for different berry species varied greatly (Table 1), ranging from $16.4 \%$ for claspleaf twisted-stalk (Streptopus amplexifolius) to $>70.0 \%$ for blueberry (Vaccinium spp.), 

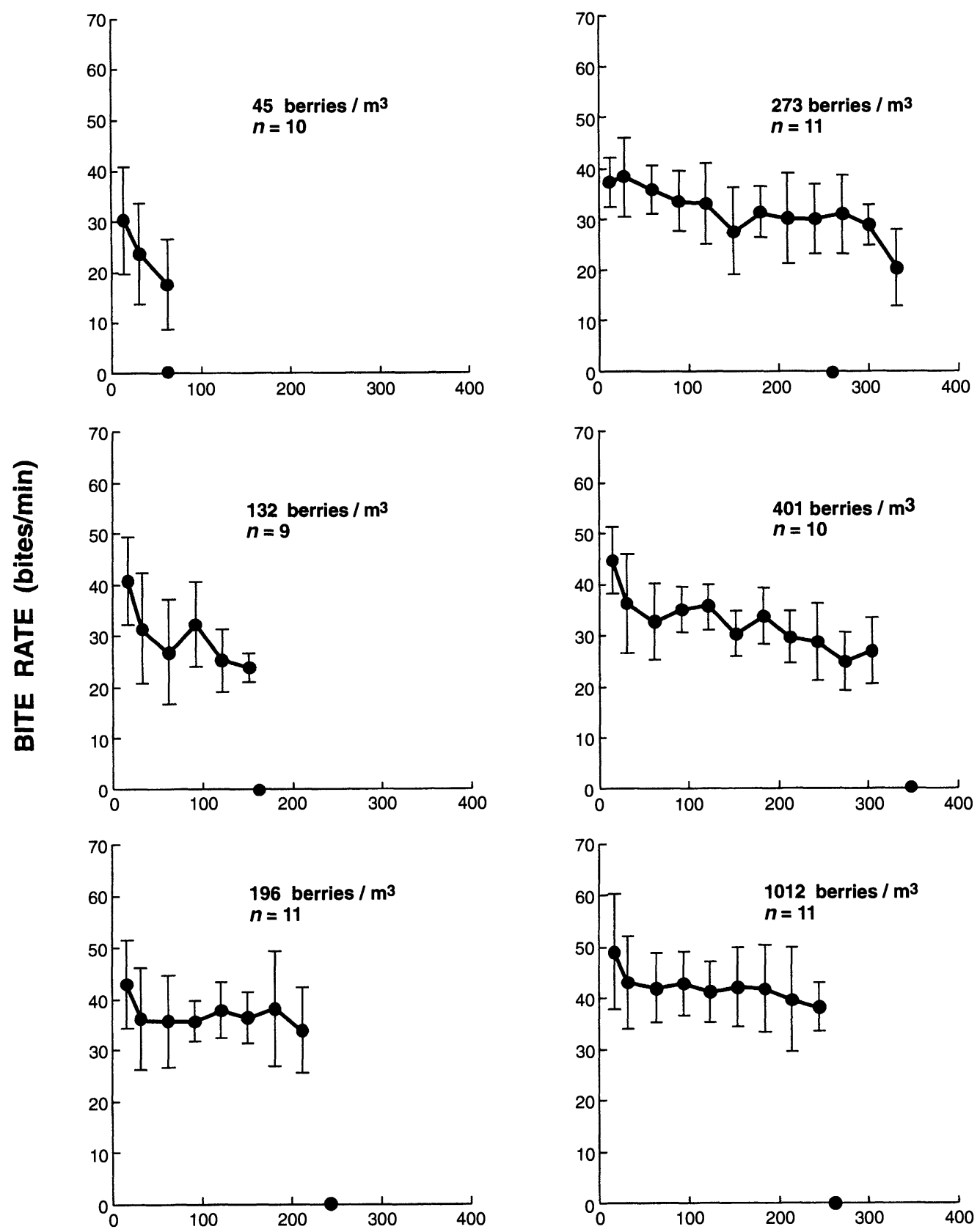

\section{TIME (seconds)}

FIG. 3. Bite rate by black and grizzly bears as a function of time elapsed during $n$ laboratory trials, for varying initial densities of huckleberries (Vaccinium membranaceum). Trials were grouped by berry density. Trial length was not uniform due to variation in "giving up" time by individual bears. Therefore, data points to the far right of a graph represent fewer trials than those on the left. All data points represent $\geq 3$ trials. The $\bullet$ on the $x$-axis represents the average trial length.

huckleberry (V. membranaceum), lowbush cranberry (V. vitis-idaea), and soapberry (Shepherdia canadensis). Serviceberry (Amelanchier alnifolia) contains more total dietary fiber than the Vaccinium berries; thus its dry matter digestibility is considerably lower at $47.1 \%$. The dry matter digestibility of serviceberry is comparable to crowberry (Empetrum nigrum, 49.2\%), an important bear food in Denali.

\section{Nutrient intake and rate of gain}

Changes in body mass for bears fed various levels of fruit were directly related to the daily digestible dry 


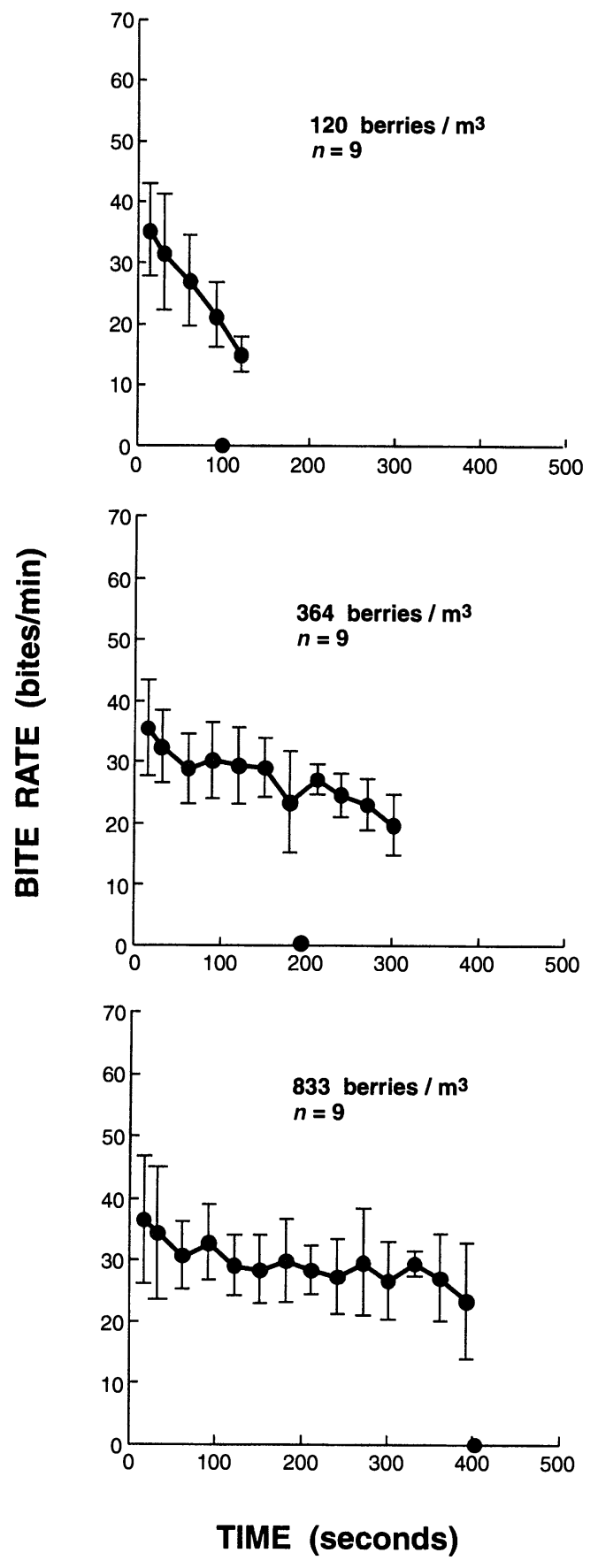

FIG. 4. Bite rate by black and grizzly bears as a function of time elapsed during laboratory trials, for varying initial densities of serviceberries (Amelanchier alnifolia). Otherwise as in Fig. 3.

matter intake (Fig. 10, $P=0.0001$ ) and did not differ significantly between bear species $(P=0.24)$. Maintenance intake averaged $80 \mathrm{~g}$ of digestible dry matter per unit of metabolic body mass.

\section{Modeling foraging and change in body mass}

Although large bears were capable of gaining body mass very rapidly when given fruit ad libitum, ingestion rates under natural conditions sharply curtailed rates of gain and, therefore, the upper size limit of wild grizzlies when berries were the main fall food resource (Fig. 11). Either black bears or grizzlies of body mass $\leq 80-100 \mathrm{~kg}$ were able to harvest enough berries to gain at the physiological maximum. However, larger bears could not gain at the maximum as they had an increasingly difficult time balancing harvesting rates with their higher daily requirements. Higher bite rates and sizes, such as those occurring in subarctic grizzlies feeding on soapberry (Shepherdia canadensis) or bog blueberry ( $V$. uliginosum) relative to Montana grizzlies feeding on more dispersed huckleberries, could significantly extend the body masses over which maximum gain occurred. The values predicted from the captive bears agreed well with the rates of gain in body mass and average adult female sizes measured for wild bears consuming berries (Fig. 11).

\section{DISCUSSION}

\section{Importance of high-grading}

The number of berries a bear could eat per minute (instantaneous intake rate) was primarily constrained by two competing processes: (1) the search time required to locate berries that were dispersed among leaves, and (2) the time it took to mechanically crop a bite. As berry density increased or berries became more clustered, berries became more apparent and search time was reduced. As search time approached zero, bite rate reached its maximum. One way bears could maintain a high bite rate, and therefore intake rate, was by moving constantly so that they were feeding only at the highest berry densities, or high-grading, as demonstrated by both wild and captive bears observed in this study. Rogers (1987) observed wild black bears moving as they ate berries, noting that they cropped the most visible berry clusters. He concluded that exclusive feeding areas (those defended and utilized by only one bear) were advantageous in this regard, as each successive forager in the area would not be able to feed as efficiently once the most visible berries had been removed. His conclusion was further strengthened by the fact that the bears with exclusive feeding areas gained more body mass than those with nonexclusive feeding areas. Pearson (1975) also noted that bears moved on before consuming all of the berries on a single bush. Other workers have made similar observations (Troyer and Hensel 1969, Linderman 1974, Gebhard 1982), indicating that high-grading is an important foraging technique for bears. The significance of high-grading was especially notable in the captive trials of this study, where bite rates generally dropped $15-20 \%$ as berry density decreased after the first 15 -s interval. These results may have implications in areas 

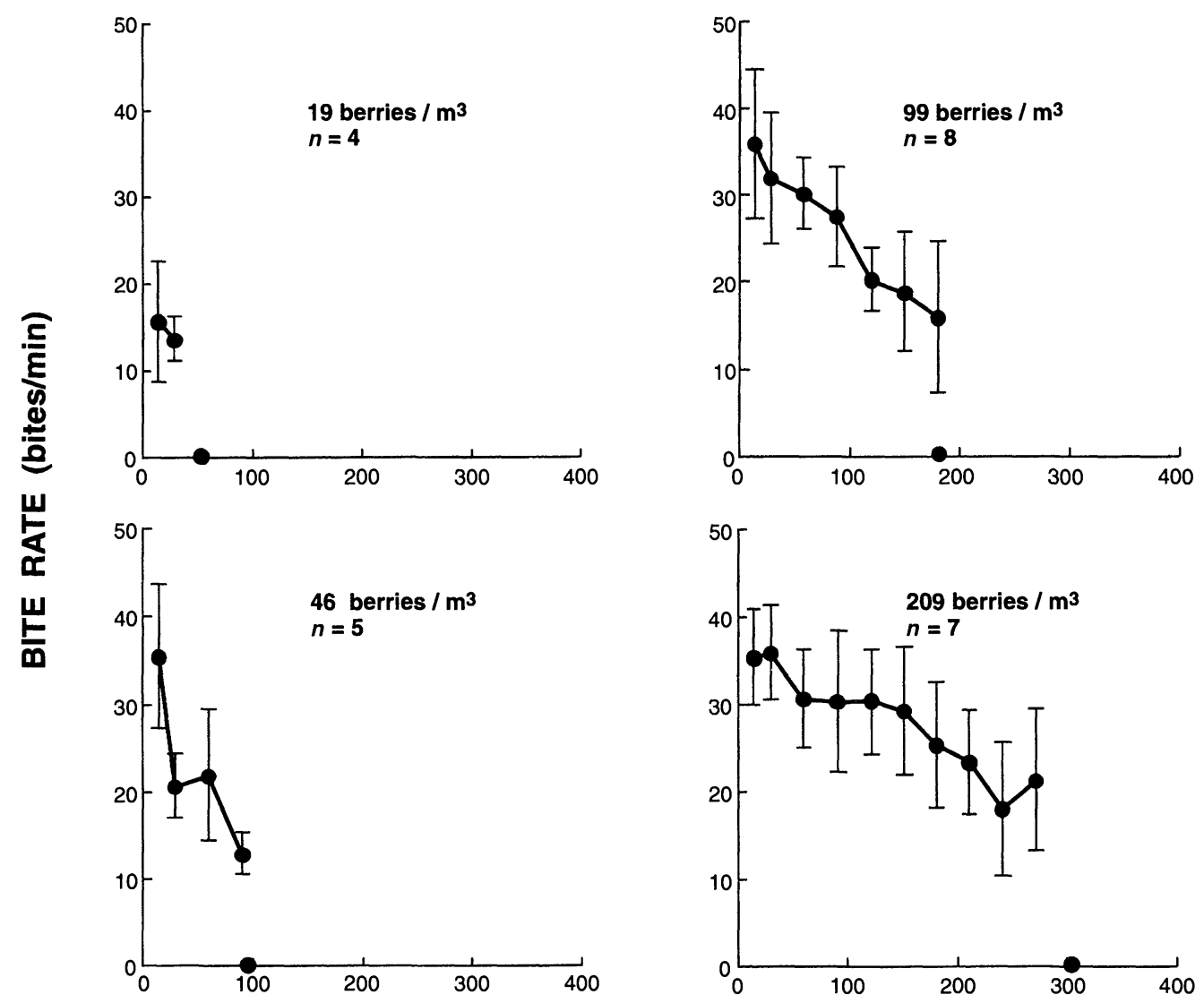

\section{TIME (seconds)}

FIG. 5. Bite rate by black and grizzly bears as a function of time elapsed during laboratory trials, for varying initial densities of small seedless red grapes (mean mass $1.8 \mathrm{~g}$ ) attached to huckleberry bushes. Otherwise as in Fig. 3.

popular for wild berry harvest, where humans, who also high-grade the most visually apparent berries, may directly compete with bears. During years of poor berry production, human berry pickers could be confined to specific locations where they would be asked to harvest all berries on the shrub, leaving the most visible berries in other locations for bears.

\section{Effect of berry density}

As long as bears were able to high-grade, berry density did not appear to influence the potential maximum bite rate when the density was $>50$ berries $/ \mathrm{m}^{3}$ (Fig. 4 ). However, adequate densities (i.e., $>50$ berries $/ \mathrm{m}^{3}$ ) must be consistently available throughout the entire berry season in order for a bear to maintain its maximum foraging efficiency. Because bears are limited by their physiological capacity to consume and convert fruit energy to fat on a daily basis, the number of days that the fruit is available (persistence) for foraging is also important. The availability of adequate berry densities can be compromised not only by the presence of other bears (Rogers 1987) and humans, but also by frugivorous birds, insects, and other mammals. In a poor berry year, blueberry consumption by animals other than bears was as high as $50 \%$ of the berry biomass produced (Pelchat and Ruff 1986). Weather, such as a hailstorm that knocks berries off the shrub (Hatler 1967), can also adversely affect berry density and persistence. Therefore, higher initial densities may be required in order to absorb these impacts and still provide the visually apparent berries at densities adequate to allow maximal foraging efficiency by bears. For example, in a year of poor blueberry (Vaccinium myrtilloides) production in Alberta (Pelchat and Ruff 1986) bears lost body mass when the annual berry density averaged 66 berries $/ \mathrm{m}^{2}$, but were able to gain when the density averaged 423 berries $/ \mathrm{m}^{2}$. In areas of high topographic relief, persistence in a single patch may be less important since delayed phenology at higher elevations extends berry availability. For example, in Glacier National Park, Montana, bears began eating huckleberries in mid-July at lower elevations (900-1200 m) and moved to higher elevations (1700-2000 m) as the season progressed. The broad interaction between berry crop persistence and the number of days necessary for bears to accumulate energy reserves sufficient for hi- 

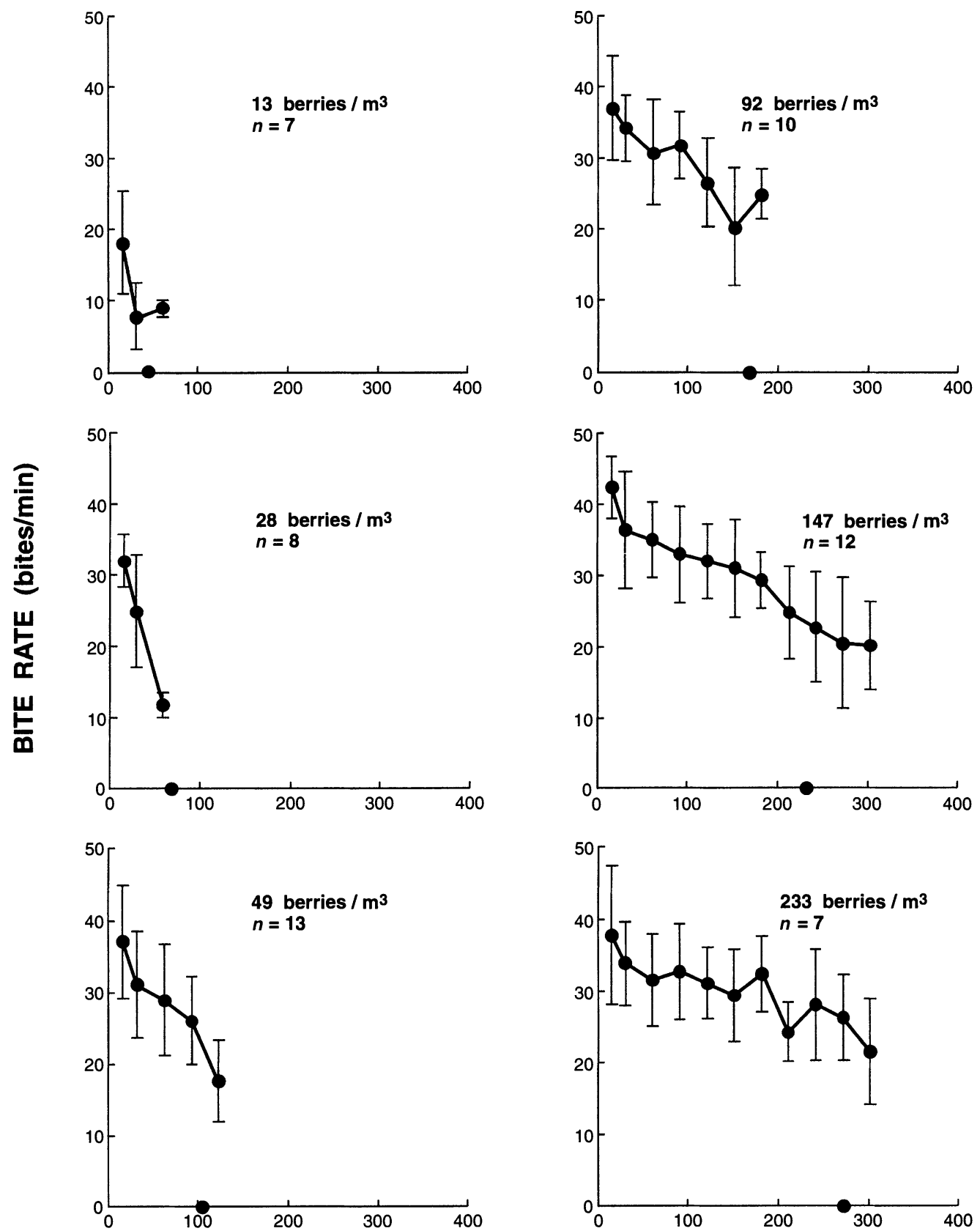

TIME (seconds)

FIG. 6. Bite rate by black and grizzly bears as a function of time elapsed during laboratory trials, for varying initial densities of large seedless red grapes (mean mass $4.2 \mathrm{~g}$ ) attached to huckleberry bushes. Otherwise as in Fig. 3.

bernation and reproduction is an important foraging constraint requiring further study.

\section{Shrub structure and berry presentation}

The structure of the shrub and presentation of the berries had an important influence on instantaneous foraging characteristics. Tall, leafy shrubs, such as huckleberry (Vaccinium membranaceum), produce fewer, singly spaced berries that are obscured by relatively large leaves. Under these circumstances, the fruit-consuming bear will be most efficient searching for and selecting individual berries. This behavior will result in lower bite rates and smaller bite sizes, as was observed for the wild bears in Glacier and the captive bears in Pullman (both foraging on V. membranaceum). In contrast, the compact, low-growing bog blueberry 

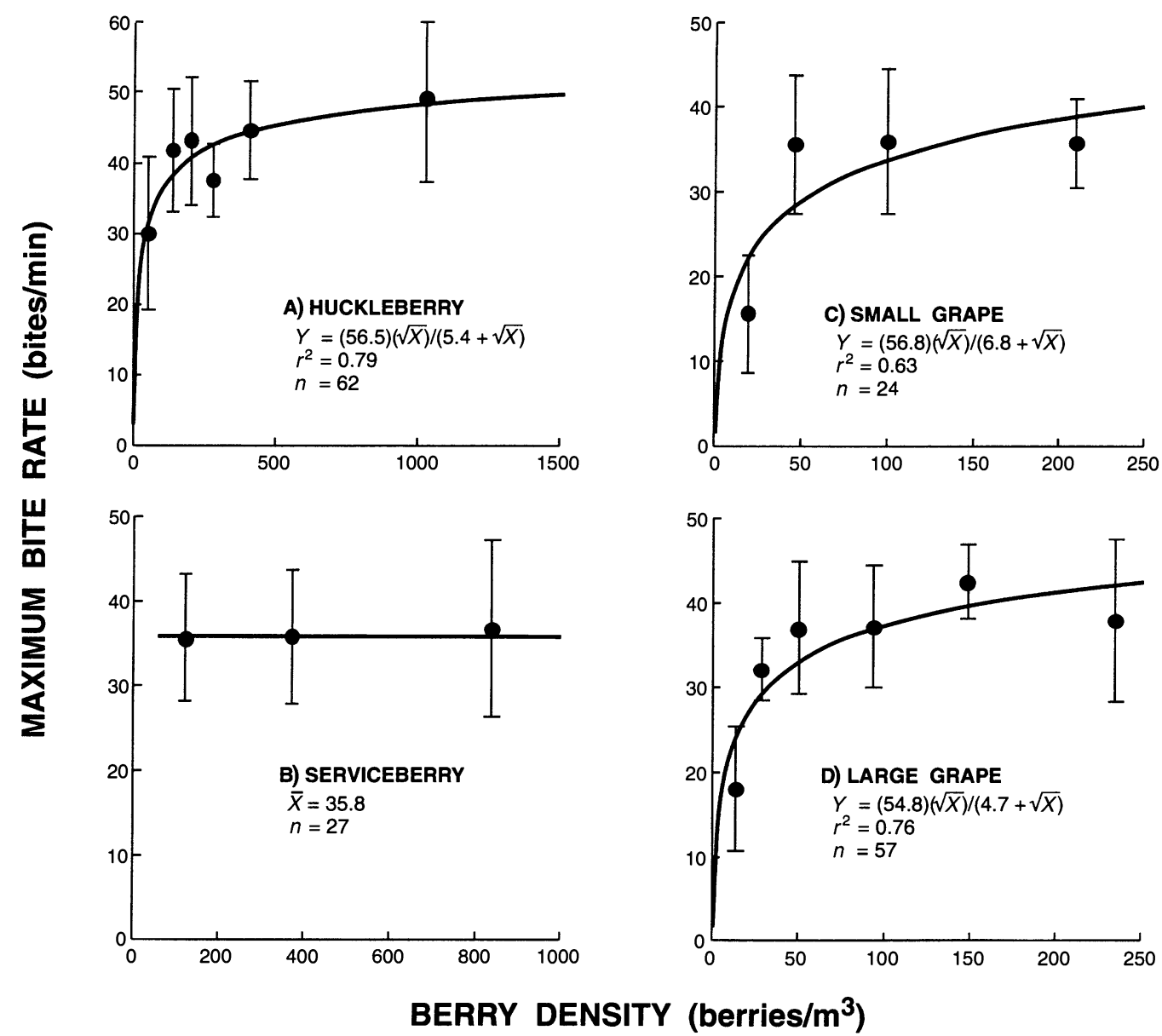

FIG. 7. Maximum bite rates as a function of initial berry density in a laboratory experiment in which captive black and grizzly bears foraged individually on each of four different berry types. Maximum bite rates were determined by averaging bite rates for the first 15-s interval across trials, for varying levels of initial berry density.

(Vaccinium uliginosum), which produces a carpet of closely spaced berries during good berry years, presumably enabled the foraging Denali bears to take the observed rapid, indiscriminate bites. Higher bite rates and greater bite sizes thus generated would allow larger bears to achieve their maximum capacity for daily gain (Fig. 11).

Berry clusters increase the efficiency of fruit consumption by improving berry visibility and accessibility. For grizzlies foraging during good berry years on soapberry (Shepherdia canadensis) in Denali, clustering of berries along the underside of the main shrub stems and the bear's ability to use a paw to raise the stems to expose the berries presumably produced larger bite sizes and the observed higher bite rates. Therefore, larger bears would be expected to select larger or clustered berries over those that are smaller or singly spaced and of comparable nutritional value. Such preferential selection for berry clusters was noted for black bears in Minnesota (Rogers 1987). For the captive bears in Pullman foraging on serviceberry (Amelanchier al- nifolia), the clustering of berries provided greater bite sizes but not higher bite rates. Bite rates remained constant and relatively low as density increased, possibly due to time expended while chewing. Serviceberry may have required significant chewing because it is more fibrous and the bite sizes often consisted of several berries, each of which may have required individual mastication. However, the relatively low leaf density and arrangement of the serviceberries along the main stem provided high visibility, which may explain why average and maximum bite rates did not decline at the lowest serviceberry densities offered.

\section{Foraging constraints and reproduction}

Together with instantaneous intake rates, the number of hours per day a bear can spend intensively foraging is important in determining its daily intake. Both black bears and grizzlies have been recorded as active during the berry season for up to 17-18 h/d (Gebhard 1982, Hechtel 1985, Rogers 1987, Lariviere et al. 1994; L. van Miltenburg et al., unpublished manuscript). The 

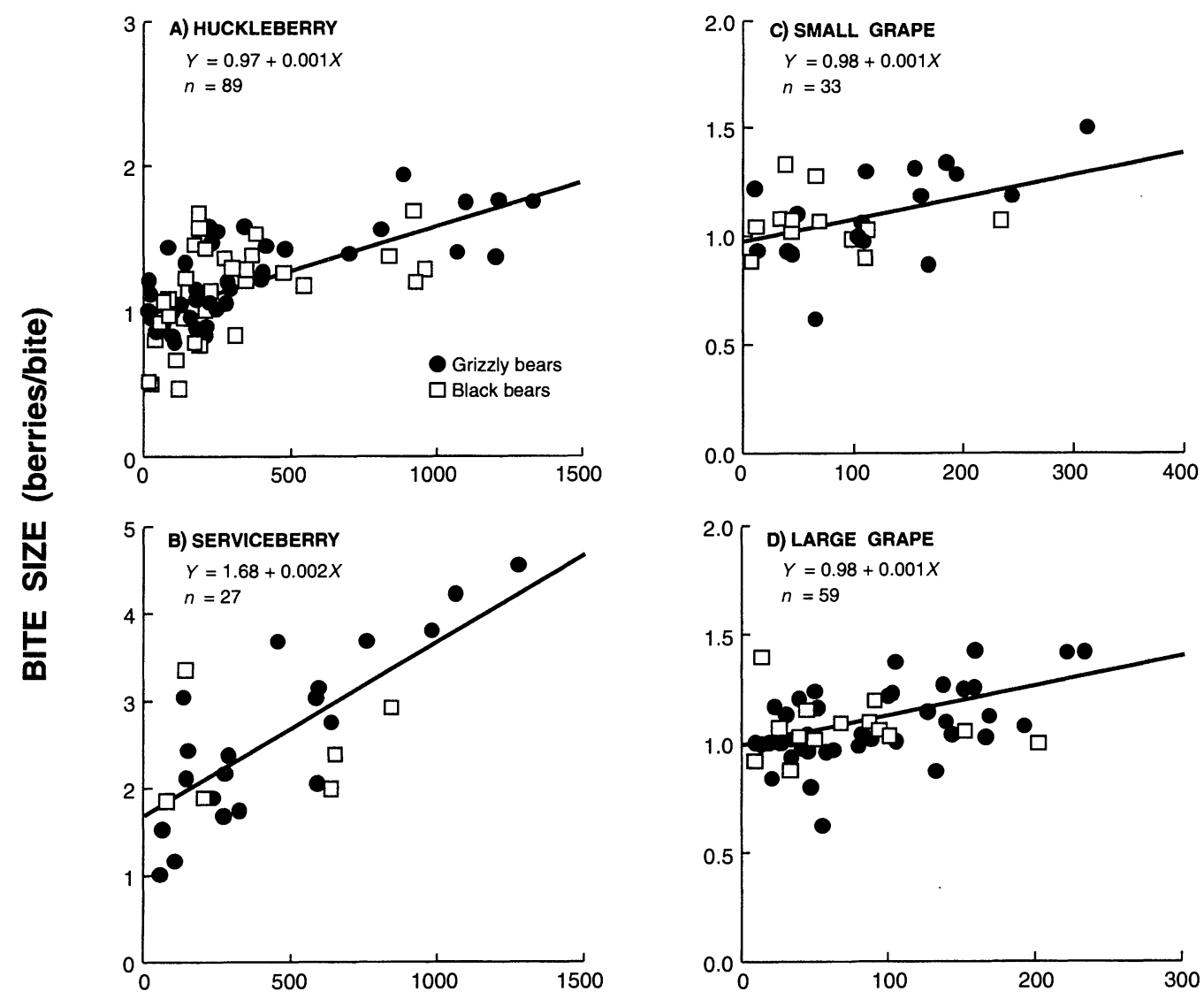

\section{BERRY DENSITY (berries/m³)}

FIG. 8. Average bite size over an entire trial as a function of initial berry density, in a laboratory experiment in which captive black and grizzly bears foraged individually on each of four different berry types.

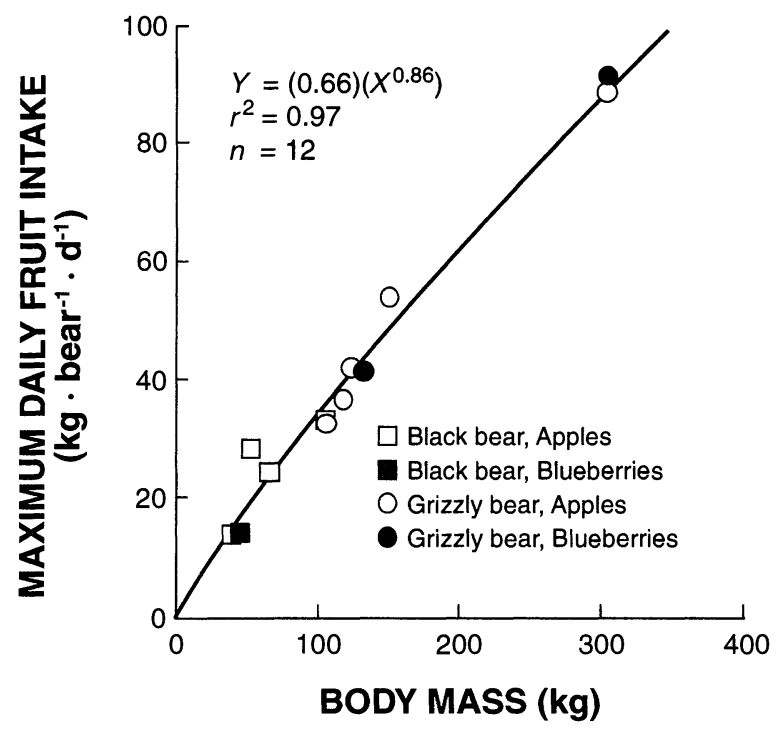

FIG. 9. Maximum daily fresh fruit intake of captive bears fed ad libitum, in relation to bear body mass. percentage of overall activity time actually spent feeding during the berry season has been estimated at $\approx 80 \%$ (Stelmock 1981, Gebhard 1982, Stelmock and Dean 1986). Based on these values, it seems reasonable to assume that a bear could feed intensively (i.e., at the maximal rates measured in this study) for $12 \mathrm{~h} / \mathrm{d}$, thus achieving the predicted gains in body mass shown in Fig. 11.

The amount of adipose tissue a female bear is able to accumulate prior to winter hibernation may play an important role in determining whether she will produce cubs the following spring (Jonkel and Cowan 1971, Rogers 1976). Because bears have one of the lowest reproductive rates of terrestrial mammals, a small decline in the annual number of cubs produced can influence the dynamics of the population (Craighead et al. 1974), although other factors, such as female mortality, may be more influential (Eberhardt 1994). Several studies have identified a strong correlation between the fall condition of the female and subsequent reproductive success (Jonkel and Cowan 1971, Rogers 1976, Young and Ruff 1982, Schwartz and Franzmann 1991). Where nutritious foods are abundant, litter sizes are 
TABLE 1. Nutritional analyses of selected wild fruit and berry species eaten by bears. Dry matter (DM) digestibility is estimated from total dietary fiber (Pritchard and Robbins 1990).

\begin{tabular}{|c|c|c|c|c|c|}
\hline Species & $\begin{array}{l}\text { Average } \\
\text { berry } \\
\text { size } \\
\text { (g/ } \\
\text { berry) }\end{array}$ & $\begin{array}{c}\text { Dry } \\
\text { matter } \\
(\%)\end{array}$ & $\begin{array}{c}\text { Crude } \\
\text { protein } \\
\text { (\% of } \\
\text { DM) }\end{array}$ & $\begin{array}{c}\text { Total } \\
\text { dietary } \\
\text { fiber } \\
(\%)\end{array}$ & $\begin{array}{l}\text { Dry } \\
\text { matter } \\
\text { digest- } \\
\text { ibility } \\
(\%)\end{array}$ \\
\hline American devil's club (Oplopanax horridum) & 0.18 & 28.6 & 6.8 & 38.3 & 48.1 \\
\hline Pulp & 0.15 & 20.3 & 5.8 & $\ldots \dagger$ & $\ldots \dagger$ \\
\hline Seed & 0.03 & 70.0 & 10.6 & 55.0 & 24.9 \\
\hline Blueberry (Vaccinium sp.) & 0.30 & 12.2 & 3.6 & 20.9 & 72.2 \\
\hline Bunchberry dogwood (Cornus canadensis) & 0.24 & 12.7 & 4.9 & 40.1 & 45.6 \\
\hline Pulp & 0.22 & 8.0 & 4.3 & $\cdots$ & $\cdots$ \\
\hline Seed & 0.02 & 55.0 & 10.0 & $\cdots$ & $\cdots$ \\
\hline Claspleaf twisted-stalk (Streptopus amplexifolius) & 0.85 & 11.8 & 12.6 & 61.1 & 16.4 \\
\hline Pulp & 0.72 & 6.8 & 9.5 & $\cdots$ & $\cdots$ \\
\hline Seed & 0.13 & 40.4 & 17.2 & $\cdots$ & $\cdots$ \\
\hline Crowberry (Empetrum nigrum) & 0.42 & 9.7 & 3.7 & 37.5 & 49.2 \\
\hline Currant (Ribes sp.) & 0.30 & 10.7 & 5.8 & 39.8 & 46.0 \\
\hline Elderberry (Sambucus sp.) & 0.19 & 15.2 & 12.0 & 34.9 & 52.8 \\
\hline Highbush cranberry (Viburnum edule) & 0.56 & 11.3 & 4.9 & 49.5 & 32.5 \\
\hline Pulp & 0.49 & 7.0 & 4.4 & $\cdots \dagger$ & $\cdots \dagger$ \\
\hline Seed & 0.07 & 39.0 & 8.1 & 67.9 & 6.9 \\
\hline Huckleberry (Vaccinium membranaceum) & 0.40 & 14.6 & 3.7 & 20.7 & 72.5 \\
\hline Lowbush cranberry (Vaccinium vitis-idaea) & 0.20 & 15.9 & 3.6 & 22.5 & 70.0 \\
\hline Mountain ash (Sorbus sp.) & 0.44 & 38.7 & $\cdots$ & 51.2 & 30.1 \\
\hline Pacific red elder (Sambucus callicarpa) & 0.07 & 17.5 & 11.8 & 57.3 & 21.7 \\
\hline Red raspberry (Rubus idaeus) & $\cdots$ & 15.1 & 4.7 & 48.1 & 34.4 \\
\hline Rose hips (Rosa sp.) & 1.09 & 31.4 & 6.2 & 42.0 & 42.9 \\
\hline Pulp & 0.91 & 23.9 & 3.5 & 31.2 & 57.9 \\
\hline Seed & 0.18 & 68.2 & 10.8 & 72.2 & 0.9 \\
\hline Serviceberry (Amelanchier alnifolia) & 0.56 & 29.2 & $\cdots$ & 39.0 & 47.1 \\
\hline Soapberry (Shepherdia canadensis) & 0.21 & 18.0 & $\ldots$ & 22.3 & 70.3 \\
\hline
\end{tabular}

$\dagger$ Measurement not performed.

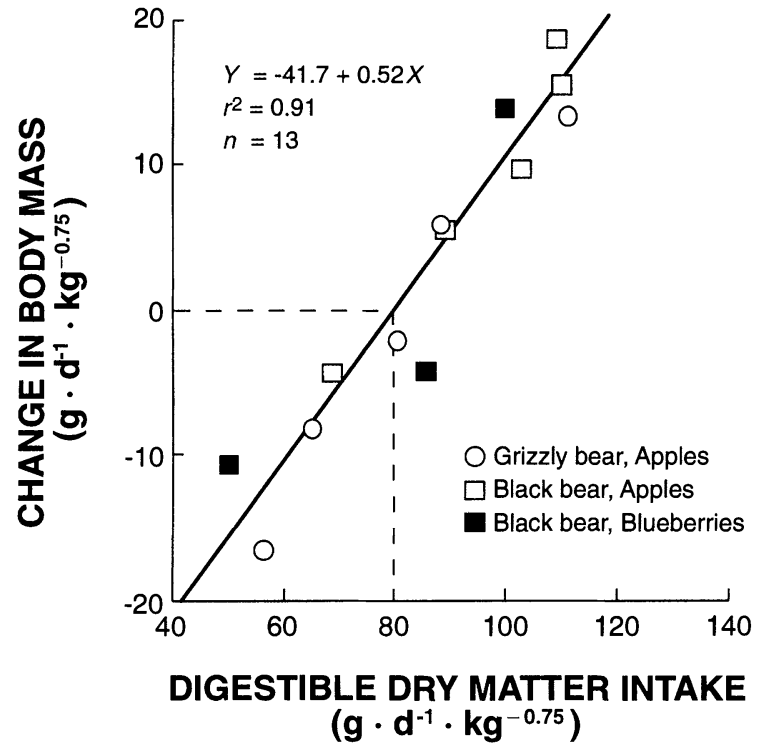

Fig. 10. Body-mass change in captive bears fed ad libitum as a function of intake of digestible dry matter. larger, the female produces her first litter earlier, and the interval between litters is shorter (Rogers 1977, 1987, Bunnell and Tait 1981, Stringham 1990). Two studies (Beecham 1980, Elowe and Dodge 1989) found that adult black bear females having body masses $<50$ $\mathrm{kg}$ as they entered hibernation failed to produce cubs. Rogers (1976) determined that black bear females weighing $<67 \mathrm{~kg}$ did not reproduce, while those weighing $>80 \mathrm{~kg}$ produced cubs in 28 of 30 cases. These successful reproductive masses fall well within the range obtainable by black bears foraging primarily on berries for fall gain in body mass (Fig. 11). Successful reproductive masses recorded for female grizzlies were higher than those recorded for black bears and range from 95 to $200 \mathrm{~kg}$ (Stringham 1990), with the heavier bears typically experiencing the highest rates of reproduction. These heavier grizzly masses are generally not attainable by bears relying on fruit for the acquisition of body fat, indicating that the smaller black bear may be better able to reach its maximum reproductive potential when foraging on small, sparsely distributed fruits. Thus, when wild fruits are the main yearly food resource for energy accumulation, bite rates, bite sizes, berry presentation, and energy availability establish strict limits to bear size. 


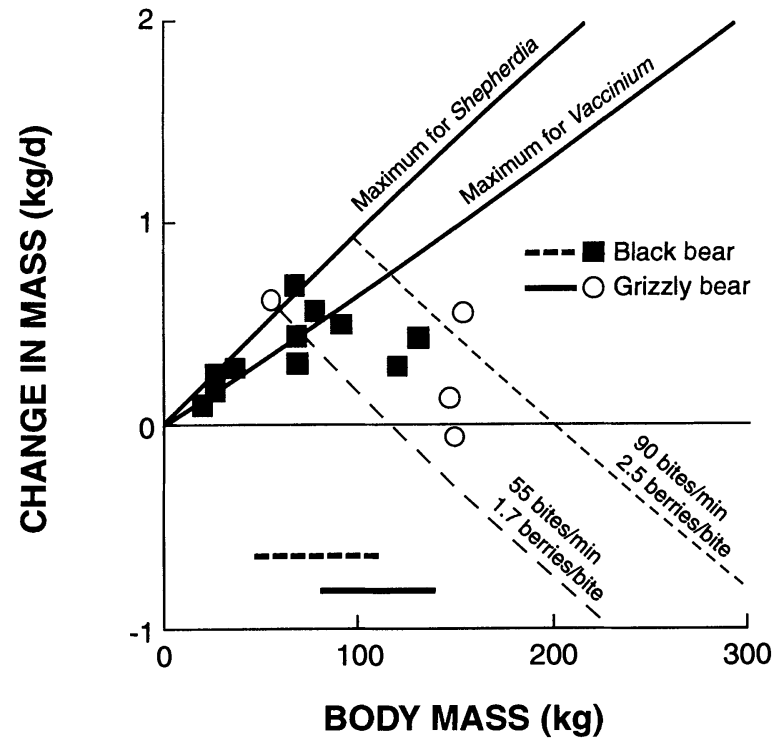

FIG. 11. Theoretical maximum and observed gains in body mass by wild bears consuming Vaccinium membranaceum or Shepherdia canadensis. The two upper lines are based on the maximum mass-specific ad libitum intake of fresh fruit (Fig. 9), the observed dry-matter content and estimated drymatter digestibilities (Table 1), and the corresponding changes in body mass at that intake of digestible dry matter (Fig. 10). The two decreasing dashed lines (V. membranaceum on left, $S$. canadensis on right) use the same data but are constrained by the specified bite rates, bite sizes, and a foraging time of $12 \mathrm{~h} / \mathrm{d}$. The individual data points are reported daily gains in body mass for wild bears feeding primarily on berries in the fall without access to major high-energy food resources such as meat, nuts, or garbage (Jonkel and Cowan 1971, Pearson 1975, Nagy et al. 1983a). The grizzly and black bear lines at the lower left of the data field are the range of mean adult female body masses in these and other populations relying primarily on berries for fall gain (Poelker and Hartwell 1973, Pearson 1975, 1976, Piekielek and Burton 1975, Russell et al. 1979, Nagy et al. 1983a, $b$, Pelchat and Ruff 1986, Schwartz and Franzmann 1991, Makarova 1992).

\section{ACKNOWLEDGMENTS}

We thank S. D. Farley and T. O'Brien for technical and statistical support; R. Johnson, R. Sayler, C. J. Whelan, and two anonymous reviewers for comments on the manuscript. We are also grateful to F. Dean, L. Maus, C. Poquette, R. Welch, L. Hale, E. Rominger, E. Reese, G. Hilderbrand, M. Jacoby, J. Olmstead, and E. Shochat for their assistance in the field. Charles Schwartz provided numerous samples of wild Alaskan berries. This research was supported by the Intermountain Research Station, United States Forest Service (Dr. J. Lyon), the National Fish and Wildlife Foundation, the Raili Korkka endowment, the United States Fish and Wildlife Service (Dr. C. Servheen), and the International Grizzly Fund (Dr. G. Ford).

\section{Literature Cited}

Bacon, E. S., and G. M. Burghardt. 1983. Food preference testing of captive black bears. International Conference on Bear Research and Management 5:102-105.

Beecham, J. J. 1980. Population characteristics, denning, and growth patterns of black bears in Idaho. Dissertation. University of Montana, Missoula, Montana, USA.

Bunnell, F. L., and T. Hamilton. 1983. Forage digestibility and fitness in grizzly bears. International Conference on Bear Research and Management 5:179-185.

Bunnell, F. L., and D. E. N. Tait. 1981. Population dynamics of bears-implications. Pages 75-98 in C. W. Fowler and T. D. Smith, editors. Dynamics of large mammal populations. John Wiley and Sons, New York, New York, USA.

Craighead, J. J., J. R. Varney, and F. C. Craighead, Jr. 1974. A population analysis of the Yellowstone grizzly bears. Montana Forest and Conservation Experiment Station, University of Montana, Missoula, Montana, USA.

Eagle, T. C., and M. R. Pelton. 1983. Seasonal nutrition of black bears in the Great Smoky Mountains National Park. International Conference on Bear Research and Management 5:94-101.

Eberhardt, L. L., B. M. Blanchard, and R. R. Knight. 1994. Population trend of the Yellowstone grizzly bear as estimated from reproductive and survival rates. Canadian Journal of Zoology 72:360-363.

Eiler, J. H., W. G. Wathen, and M. R. Pelton. 1989. Reproduction in black bears in the southern Appalachian Mountains. Journal of Wildlife Management 53:353-360.

Elowe, K. D., and W. E. Dodge. 1989. Factors affecting black bear reproductive success and cub survival. Journal of Wildlife Management 53:962-968.

Gebhard, J. G. 1982. Annual activities and behavior of a grizzly bear (Ursus arctos) family in northern Alaska. Thesis. University of Alaska, Fairbanks, Alaska, USA.

Gross, J. E., L. A. Shipley, N. T. Hobbs, D. E. Spalinger, and B. A. Wunder. 1993. Functional response of herbivores in food-concentrated patches: tests of a mechanistic model. Ecology 74:778-791.

Hatler, D. F. 1967. Some aspects in the ecology of the black bear (Ursus americanus) in interior Alaska. Thesis. University of Alaska, Fairbanks, Alaska, USA.

1972. Food habits of black bears in interior Alaska The Canadian Field-Naturalist 86:17-31.

Hechtel, J. L. 1985. Activity and food habits of barrenground grizzly bears in Arctic Alaska. Thesis. University of Montana, Missoula, Montana, USA..

Jonkel, C., and I. McT. Cowan. 1971. The black bear in the spruce-fir forest. Wildlife Monographs 27:1-57.

Lariviere, S., J. Huot, and C. Samson. 1994. Daily activity patterns of female black bears in a northern mixed-forest environment. Journal of Mammalogy 75:613-620.

Linderman, S. 1974. Ground tracking of arctic grizzly bears. Final report. Federal Aid in Wildlife Restoration Project W-17-6. Job 4.12R. Alaska Department of Fish and Game, Juneau, Alaska, USA.

Mace, R. D., and C. J. Jonkel. 1986. Local food habits of the grizzly bear in Montana. International Conference on Bear Research and Management 6:105-110.

Makarova, O. A. 1992. The brown bear of the Kola Peninsula. Pages 363-365 in B. Bobek, K. Perzanowski, and W. Regelin, editors. Global trends in wildlife management. Swiat, Krakow-Warszawa, Poland.

Martinka, C. J. 1976. Ecological role and management of grizzly bears in Glacier National Park, Montana. International Conference on Bear Research and Management 3: 147-156.

Motulsky, H. J., and L. A. Ransnas. 1987. Fitting curves to data using nonlinear regression: a practical and nonmathematical review. Federation of American Societies for Experimental Biology Journal 1:365-374.

Nagy, J. A., A. M. Pearson, R. H. Russell, M. C. S. Kingsley, and B. C. Goski. 1983a. Ecological studies of grizzly bears in the Arctic Mountains, northern Yukon Territory, 19721975. Canadian Wildlife Service, Edmonton, Canada.

Nagy, J. A., R. H. Russell, A. M. Pearson, M. C. S. Kingsley, and C. B. Larsen. 1983b. A study of grizzly bears on the barren grounds of Tuktoyaktuk Peninsula and Richards Is- 
land, Northwest Territories, 1974-1978. Canadian Wildlife Service, Edmonton, Canada.

Noyce, K. V., and P. L. Coy. 1990. Abundance and productivity of bear food species in different forest types of northcentral Minnesota. International Conference on Bear Research and Management 8:169-181.

Pearson, A. M. 1975. The northern interior grizzly bear, Ursus arctos L. Canadian Wildlife Service Report Series No. 34. Canadian Wildlife Service, Edmonton, Canada.

1976. Population characteristics of the Arctic Mountain grizzly bear. International Conference on Bear Research and Management 3:247-259.

Pelchat, B. O., and R. L. Ruff. 1986. Habitat and spatial relationships of black bears in the boreal mixedwood forest of Alberta. International Conference on Bear Research and Management 6:81-92.

Piekielek, W. and T. S. Burton. 1975. A black bear population study in northern California. California Fish and Game 61: 4-25.

Pielou, E. C. 1977. Mathematical ecology. John Wiley and Sons, New York, New York, USA.

Poelker, R. J., and Hartwell, H. D. 1973. Black bear of Washington. Washington State Game Department, Olympia, Washington, USA.

Powell, R. A., and D. E. Seaman. 1990. Production of important black bear foods in the southern Appalachians. International Conference on Bear Research and Management 8:183-187.

Pritchard, G. T., and C. T. Robbins. 1990. Digestive and metabolic efficiencies of grizzly and black bears. Canadian Journal of Zoology 68:1645-1651.

Real, L. A. 1977. The kinetics of functional response. American Naturalist 111:289-300.

Rogers, L. 1976. Effects of mast and berry crop failures on survival, growth, and reproductive success of black bears. Transactions of the North American Wildlife and Natural Resource Conference 41:431-438.

- 1977. Social relationships, movements, and population dynamics of black bears in northeastern Minnesota. Dissertation. University of Minnesota, Minneapolis, Minnesota, USA.

1987. Effects of food supply and kinship on social behavior, movements, and population growth of black bears in northeastern Minnesota. Wildlife Monographs 97:1-72.
Russell, R. H., J. W. Nolan, N. A. Woody, and G. Anderson. 1979. A study of the grizzly bear (Ursus arctos L.) in Jasper National Park, 1975-1978. Final report. Canadian Wildlife Service, Edmonton, Canada.

SAS Institute. 1985. SAS user's guide: statistics. Version five. SAS Institute, Cary, North Carolina, USA.

Schwartz, C. C., and A. W. Franzmann. 1991. Interrelationship of black bears to moose and forest succession in the northern coniferous forest. Wildlife Monographs 113:1-58.

Servheen, C. 1983. Grizzly bear food habits, movements, and habitat selection in the Mission Mountains, Montana. Journal of Wildlife Management 47:1026-1035.

Shipley, L. A., and D. E. Spalinger. 1992. Mechanics of browsing in dense food patches: effects of plant and animal morphology on intake rate. Canadian Journal of Zoology 70:1743-1752.

Spalinger, D. E., T. A. Hanley, and C. T. Robbins. 1988. Analysis of the functional response in foraging in the Sitka black-tailed deer. Ecology 69:1166-1175.

Spalinger, D. E., and N. T. Hobbs. 1992. Mechanisms of foraging in mammalian herbivores: new models of functional response. American Naturalist 140:325-348.

Spiller, G. A. 1993. Dietary fiber in human nutrition. CRC, Boca Raton, Florida, USA.

Stelmock, J. 1981. Seasonal activities and habitat use patterns of brown bears in Denali National Park-1980. Thesis. University of Alaska, Fairbanks, Alaska, USA.

Stelmock, J., and F. C. Dean. 1986. Brown bear activity and habitat use, Denali National Park-1980. International Conference on Bear Research and Management 6:155-167.

Stringham, S. F. 1990. Grizzly bear reproductive rate relative to body size. International Association for Bear Research and Management 8:433-443.

Troyer, W. A., and R. J. Hensel. 1969. The brown bear of Kodiak island. Kodiak National Wildlife Refuge Report. U.S. Fish and Wildlife Service, Kodiak, Alaska, USA.

Wickstrom, M. L., C. T. Robbins, T. A. Hanley, D. E. Spalinger, and S. M. Parish. 1984. Food intake and foraging energetics of elk and mule deer. Journal of Wildlife Management 48:1285-1301.

Young, B. F., and R. L. Ruff. 1982. Population dynamics and movements of black bears in east central Alberta. Journal of Wildlife Management 46:845-860. 